in the established series to maintain continuity with the twelve preceding conferences which were sponsored by the National Academy of Sciences-National Research Council.

This volume maintains the high standard of contribu. tions and production of its predecessors, including the index which makes the series a valuable work of reference as well as a record of conference contributions.

The first ten papers record the symposium on Structural Aspects of Layer Silicates with which the conference opened. In the general sessions which followed there were eight papers on various aspects of natural clays traditional clay mineralogy but including an interesting account of the use of automated $\mathrm{X}$-ray diffraction equipment. The final nineteen papers were more general in character, and included a description of the swelling properties of natural and artificial clays; infra-red and differential thermal analysis; ion exchange; the use of organoclays in producing radiation bonded polyethylene material resistant to solvents; electron microscopy and diffraction particularly for following the early reactions of kaolinite attacked by sodium hydroxide and calcium hydroxide; the effects of low temperature heat treatment and the thermodynamics of high temperature transformations; rheology of clays.

The appendix is a valuable record of the present state of nomenclature in this particularly difficult field. The book is altogether a valuable addition to the series which all those interested in work on clays will want to have for reference.

J. W. JEFFERY

\section{NATURAL PRODUCTS}

\section{The Molecules of Nature}

A Survey of the Biosynthesis and Chemistry of Natural Products. By James B. Hendrickson. (The Organic Chemistry Monographs Series.) Pp. xiii + 189. (New York and Amsterdam: W. A. Benjamin, Inc., 1965.) $\$ 7.70$.

THIs book, subtitled $A$ Survey of the Biosynthesis and Chemistry of Natural Products, consists of five sections: an introductory prologue, a general survey of the biosynthesis of natural products and throe chapters on selected natural products-the acetogenins (a torm not well received in Britain) and phenylpropanes, the terpenes and sterols, and the alkaloids. In the United States the book is intended mainly for advanced undorgraduate courses; in Britain it can readily be recommended as a stimulating outline of natural product chemistry to students reading for honours in organic chemistry. It is probably too condonsed to be useful to any but the most chemically minded undergraduates in biochemistry, but it would be useful prescribed reading for research students working in biochemical laboratories investigating biosynthetic problems.

The well known investigations of Cornforth and Popják have demonstrated the briliant achievements in bio. synthetic investigations which can emerge from sympathetic collaboration betwoen organic chemists and biochemists, and this type of collaboration must become more wid3sproad if progress is to continue in this diffeult field. Therefore it is important for undergraduate chemists and biochemists to appreciate the contribution which each discipline can make to the general problem of biosynthesis. Unfortunately this book, in spite of its subtitle, does not successfully provide a satisfactory picture of the role of the biochemist, for in spite of providing a pattern for a genoralized view of the probable origins of natural products, the second chapter is biochemically superficial and occasionally incorrect. (For examplo, there are two mistakes in Chart 7 on the biosynthesis of the terpenes.)

The chapters on the natural products themselves are much more successful, and a useful innovation is the indication by the sign at the end of a paragraph that the evidence for the solution of a structural problem is complete and that the solution follows in the next paragraph. This allows the enquiring student to try to solve the problem before reading the solution.

Altogether an interesting book and one worthy of a place in the library of most departments of chemistry and biochemistry to serve, as the author himself appro. priately suggests, as a kind of dessert.

T. W. GoodwIN

\section{STEREOSPECIFIC ELASTOMERS}

\section{Elastomer Stereospecific Polymerization}

(A Symposium sponsored by the Division of Rubber Chemistry and the Division of Polymer Chemistry at the 148th Meeting of the American Chemical Society, Chicago, Ill., September 2, 1964. Advances in Chemistry Series, No. 52.) Pp. vii + 155. (Washington, D.C.: American Chemical Society, 1966.) \$5.50.

THIs short book is a collection of eleven papers contributed to a symposium sponsored by the Divisions of Rubber and Polymer Chemistry of the American Chemical Society. There is no doubt that the material presented is of high standard and is, on the whole, very relevant to the problem of stereospecific polymerization. The purpose of the book is presumably to present a picture of this symposium which would otherwise be lost by publication of the papers in a number of journals. At the same time, the discussion which must have taken place is omitted. One is left wondering whether the effort of publication in this form is really worth while, especially when the cost $(\$ 5.50)$ is high.

Except for an excellent review of aldehyde polymerization, the papers are concerned with the polymerization of individual diene monomers by catalysts based either on lithium alkyls or on Ziegler--Natta systems. Indeed, leaving aside a review of organometallic polymerization by Morton, the papers are exactly of the kind we would expect to find in a journal and range from the very theoretical to the intensely practical.

In short, the material is good, the price is high, but was it worth the effort?

G. M. BURNETT

\section{NUCLEIC ACID CHEMISTRY}

\section{Procedures in Nucleic Acid Research}

Editod by G. L. Cantoni and David R. Davies. Pp. xvi +667 . (New York and London: Harper and Row, Publishers, 1966.) $200 s$.

IN this day and age any publication on nucleic acids is bound to attract attention, and to acquire all the books on the subject must prove a very costly business. This book, howover, is a must, for it has been put together with groat care by the editors with a formidable team of no fewer than seventy woll known specialists in the fiold.

The coverage has boen arranged in various sections under the two main headings, "Enzymes of Nucleic Acid Motabolism" and "Isolation, Preparation and Characterisation of Natural and Synthetic Nucleic Acids". Each of the chapters is clear and authoritative and makes fascinating reading for the non-specialist as well as the spocialist. References aro up to date to 1965. Author and subject indexes are provided. Although the whole picture of nucleic acid structure and function is changing rapidly, this compendium will bo most useful as a referenco book for a considerable time to come. Meanwhile it will also serve to bring interested workers well up to date. It can be strongly rocommonded. M. StrAcer 